\title{
Genetic evidence for the conversion of the morphinan alkaloid thebaine to oripavine in interspecific hybrids between Papaver bracteatum and Papaver orientale*
}

\author{
J. Milo, \\ A. Levy,* \\ D. Palevitch* and \\ G. Ladizinsky $\dagger$
}

\author{
* Dept. of Medicinal, Spice and Aromatic Plants, \\ Agricultural Research Organization, The Volcani \\ Centre, Bet-Dagan 50-250, Israel. \\ $\dagger$ Hebrew University, Faculty of Agriculture, Rehovot, \\ Israel.
}

The alkaloid profiles of ripe capsules of Papaver bracteatum, $P$. orientale and their interspecific hybrids $\left(F_{1}\right.$ and $B C F_{1}$ ) were determined and compared. In the hybrids the thebaine content declined, while that of oripavine was higher than in the parental species. The results provided genetic evidence for the biosynthetic linkage between those alkaloids. A genetic model, assuming dosage effect interaction between the genomes of the two species was elaborated. The significance of the results for breeding purposes was considered.

\section{INTRODUCTION}

The species Papaver bracteatum and $P$. orientale of the section Oxytona are considered as potential plant sources of opiates. In $P$. bracteatum thebaine is found almost exclusively at a content of $1 \cdot 5-3 \cdot 8$ per cent of the dry weight of the ripe capsules, depending on the plant population (Lalezari et al., 1974; Levy et al., 1979). This alkaloid can be used as a precursor for codeine production in the pharmaceutical industry. Oripavine is the major alkaloid of $P$. orientale $(0 \cdot 5-1 \cdot 15$ per cent in dry capsules) in all chemotypes having the characteristic chromosome number of the species $(2 n=28)$ and thebaine was reported as a minor alkaloid in this species (Shafiee et al., 1975; 1977).

A similar pathway for thebaine biosynthesis was shown to operate in $P$. somniferum, $P$. bracteatum and $P$. orientale (Brochmann-Hanssen and Wunderly, 1978; Hodges et al., 1977; Stermitz and Rapoport, 1961). The biosynthetic steps were determined using radioactive tracers and it was shown that the demethylation of the enol ether group of thebaine, which proceeds in $P$. som-

\footnotetext{
* Contribution no. 2793-E, 1989 series from the Agricultural Research Organization, The Volcani Center, Bet-Dagan 50-250, Israel.
}

niferum to the production of codeine and morphine, is blocked in P. bracteatum (Horn et al., 1978). Likewise in $P$. orientale thebaine is further metabolised to two phenolic compounds, one of which is presumed to be oripavine (Stermitz and Rapoport, 1961).

In the present study the alkaloid profiles and content of $P$. bracteatum, $P$. orientale and their interspecific hybrid were analysed. The variations in the relative concentrations of thebaine and oripavine in the various genotypes were compared in order to detect genomic interactions and biosynthetic linkage between the major alkaloids of the two species.

\section{MATERIAL AND METHODS}

Accessions of $P$. bracteatum $(2 n=14)$ and $P$. orientale $(2 n=28)$, originating from Iran, were sown in a greenhouse and the seedlings were transplanted to the field; reciprocal crosses were made between the two species and the backcross of the hybrid to $P$. bracteatum was performed in the following season. Three different $F_{1}$ and two $B C F_{1}$ families resulting from crosses between different parental plants were grown in the field along with the parents. The chromosome number of each 
species and hybrid was examined in the pollen mother cells as previously described (Milo et al, 1988). Ten plants from each parent, $F_{1}$ and $B C F_{1}$ families were sampled randomly for chemical analysis. Capsules from individual plants were collected separately, oven dried $\left(50^{\circ} \mathrm{C}\right)$ and, following alkaloid extraction, submitted to chemical analysis (Fairbairn and Helliwell, 1975).

A quantitative reversed-phase high pressure liquid chromatographic method was used for the analysis of the alkaloid spectrum. The separation was accomplished on a LiChrosorb Supersphere ${ }^{\circledR}$ RP-18 column (Merck, particle size $4 \mu \mathrm{m}$, $125 \mathrm{~mm} \times 4 \mathrm{~mm}$ I.D.); the mobile phase was 5 per cent 2-propanol, 40 per cent acetonitrile, 55 per cent water with 1 per cent ammonium carbonate. The solvent flow-rate was $1 \mathrm{ml} / \mathrm{min}$ and detection was at $280 \mathrm{~nm}$. For a detailed description of the extraction and separation of the alkaloids, see Milo et al. (1989).

\section{RESULTS AND DISCUSSION}

\section{Meiotic behaviour of the hybrid}

The $\mathrm{F}_{1}$ hybrid $(2 n=21)$ between $P$. bracteatum and $P$. orientale had bivalents, univalents and a low frequency of trivalents at metaphase I (fig. 1(a)). Unequal migration of chromosomes at anaphase I was observed (fig. 1(b), (c)), resulting in unbalanced gametes and a high degree of sterility ( 8 per
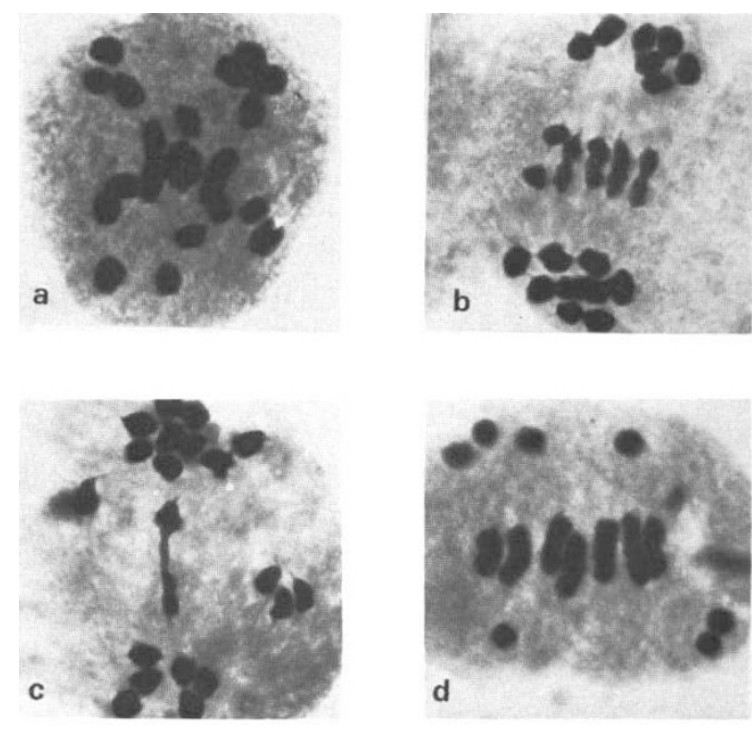

Figure 1 Chromosome associations at meiosis in $F_{1}$ (Papaver bracteatum $\times P$. orientale): (a) metaphase $I ;(b, c)$ anaphase $\mathrm{I}$; and in $\mathrm{BCF}_{1}(P$. bracteatum $\times P$. orientale $) \times P$. bracteatum: (d) metaphase I. cent pollen stainability). All the plants obtained from the backcross to the diploid parent were triploids $(2 n=21$, fig. $1(\mathrm{~d}))$, indicating that the fertile gametes of the $F_{1}$ had 14 chromosomes. This feature should be borne in mind when elaborating a model for the interactions between the genomes of the two species.

\section{Alkaloid spectrum}

In the diploid species P. bracteatum $(2 n=14)$, only thebaine was present. The alkaloid spectrum of the tetraploid species $P$. orientale $(2 n=28)$ was wider and included thebaine, oripavine and alpinigenine at concentrations of $0.061,0.086$ and 0.080 per cent, respectively; as well as isothebaine and salutaridine as minor alkaloids (table 1, fig. 2 ). As expected for natural populations of outcrossing species, a large chemical variation between and within families was observed for the concentrations of the different alkaloids. The alkaloid spectrum of the hybrid between $P$. bracteatum and $P$. orientale was different from that of either parent and contained only thebaine and oripavine. The concentration of the latter compound was up to ten times higher in the hybrid than in $P$. orientale; likewise, its thebaine content was much lower than that of $P$. bracteatum. Moreover, the plants of the backcross generation to $P$. bracteatum had even higher oripavine and lower thebaine contents than the $F_{1}$ hybrid. Similar findings have been reported in interspecific hybrids between $P$. somniferum and $P$. bracteatum; in the hybrids, a higher codeine content and a lower thebaine content were found compared with $P$. somniferum (Bohm and Nixdorf, 1983). It is noteworthy that the minor alkaloids present in $P$. orientale are completely lacking in the ripe capsules of the hybrid. The minor non-morphinan alkaloids of $P$. orientale which disappeared in the interspecific hybrid belong to different branches of the biosynthetic pathway in these plants (Phillipson, 1983). Whether these alkaloids are not synthesized, or their formation occurs during the early stages of plant development and they are subsequently degraded, as in the case of $P$. bracteatum (Bohm, 1967; Nyman and Bruhn, 1979), remains to be determined. The alkaloid spectrum and especially the ratio between the morphinan and non-morphinan alkaloids were found to be affected by the ploidy level of the plants (Milo and Levy, 1989).

When no biosynthetic linkage between the compounds of the parents prevails, the hybrids exhibit generally an intermediate spectrum, includ- 
Table 1 The alkaloid content (per cent dry weight; range given in parentheses) in capsules of Papaver bracteatum (PB), $P$. orientale (PO) and their interspecific hybrids.

\begin{tabular}{llllll}
\hline $\begin{array}{l}\text { Species } \\
\text { or hybrid }\end{array}$ & Thebaine & Oripavine & Alpinigenine & Salutaridine & Isothebaine \\
\hline PB & $2 \cdot 15$ & & & \\
& $(1.24-3.75)$ & & & \\
PO & 0.061 & 0.086 & 0.080 & 0.002 & 0.029 \\
& $(0.020-0.130)$ & $(0.020-0.125)$ & $(0.032-0.128)$ & $(0.001-0.004)$ & $(0.001-0.085)$ \\
$F_{1}$ & 0.193 & 0.522 & & \\
& $(0.007-0.710)$ & $(0.250-1.04)$ & & \\
$\mathrm{BCF}_{1}$ & 0.129 & 0.779 & & \\
& $(0.022-0.268)$ & $(0.502-1 \cdot 126)$ & & \\
\hline
\end{tabular}
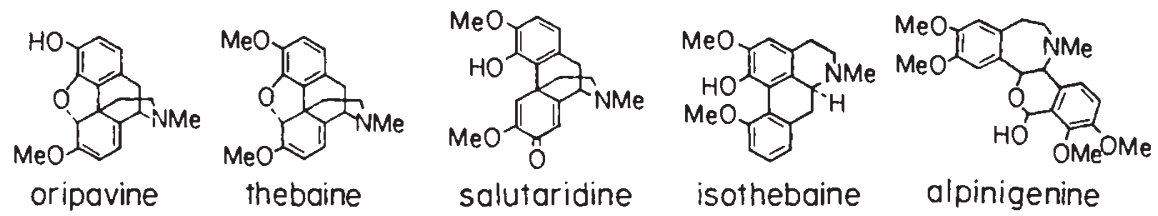

Figure 2 Structures of the major alkaloids of Papaver section Oxytona. $\mathrm{Me}=$ methyl.

ing the compounds of both parents (Waller and Nowacki, 1978). In this study, the alkaloid profile of the interspecific hybrid can be explained if the conversion of thebaine to oripavine by the genome of $P$. orientale is considered. The high thebaine content, synthesized by the $P$. bracteatum genome, is further metabolized to oripavine by the enzymatic system of $P$. orientale.

A significant $(P<0 \cdot 05)$ positive correlation $(r=0.63)$ was found in all the plant populations between the total morphinan alkaloid content and the ratio of oripavine to thebaine: when the total content is higher, the oripavine concentration increases at the expense of thebaine. Hence, in $P$. orientale, which has a low alkaloid concentration, thebaine and oripavine were present in about equal amounts, whereas in the hybrid containing a high alkaloid concentration, 59-97 per cent of the total alkaloids were in the demethylated form of oripavine. These findings indicate that the efficiency of the enzymatic demethylation process increases at higher concentrations of the thebaine substrate.

Two genomic interactions may be responsible for this situation, as illustrated in table 2 . In model I, additive effects of the parental genomes are assumed; hence, the expected morphinan alkaloid content in the hybrid is the arithmetic mean of the concentrations of the parents. In model II, a genomic interaction with dosage effect is considered between the two genomes of the parents. The hybrid has one set of chromosomes $(n=7)$ from the diploid parent and two sets of chromosomes from the tetraploid parent. In the backcross generation, two sets of chromosomes $(n=14)$ are transferred from the $\mathrm{F}_{1}$ parent and one set $(n=7)$

Table 2 Two models for estimation of the expected total morphinan alkaloids in hybrids of Papaver bracteatum (PB) and P. orientale (PO)

\begin{tabular}{llll}
\hline & & $\begin{array}{l}\text { Genomic } \\
\text { constitution }\end{array}$ & $\begin{array}{l}\text { Alkaloid content } \\
\text { (per cent of dry wt.) }\end{array}$ \\
\hline$F_{1}$ & Model I & $1 / 2(\mathrm{~PB})+1 / 2(\mathrm{PO})$ & $1 \cdot 148 \pm 0 \cdot 197^{*}$ \\
& Model II & $1 / 3(\mathrm{~PB})+2 / 3(\mathrm{PO})$ & $0 \cdot 814 \pm 0 \cdot 172$ \\
& Observed & & $0 \cdot 715 \pm 0 \cdot 074$ \\
$\mathrm{BCF}_{1}$ & Model I & $1 / 2\left(\mathrm{~F}_{1}\right)+1 / 2(\mathrm{~PB})$ & $1 \cdot 432 \pm 0 \cdot 174$ \\
& Model II & $2 / 3\left(\mathrm{~F}_{1}\right)+1 / 3(\mathrm{~PB})$ & $1 \cdot 192 \pm 0 \cdot 140$ \\
& Observed & & $0 \cdot 908 \pm 0 \cdot 053$ \\
\hline
\end{tabular}

* Mean +S.E. 
from $P$. bracteatum, as demonstrated by the cytological analysis. This ratio is retained in the calculation of the expected alkaloid content. The total alkaloid content of the $F_{1}$ and $\mathrm{BCF}_{1}$ fits better with model II $\left(\chi^{2}=0.08,0.7<P<0.8\right)$, assuming genetic interaction between the genomes of the two parental species. Dosage effects were also detected in these hybrids for various isozymes (Milo et al., 1988), indicating further evidence for such an interaction between the genomes of these species. The genomal interaction between $P$. orientale and $P$. bracteatum, and the conversion of thebaine to oripavine in the hybrids, should be considered in breeding programs aiming at combining high thebaine content with desirable agronomic characters from both species. The genes controlling the demethylation of thebaine to oripavine should be eliminated by backcross to $P$. bracteatum: however, the differences in ploidy level between the two species might make this task difficult.

Acknowledgements This research forms part of J. Milo's Ph.D. Thesis and was supported in part by grant no. J-368-81 from the United States-Israel Binational Agricultural Research and Development Fund (BARD).

\section{REFERENCES}

вонм, н. 1967. Uber Papaver bracteatum III. Mitteilung charakteritische veranderung des alkaloidspektrums wahrend der pflanzentwicklung. Planta Med., 15, 215-220.

BOHM, H. AND NIXDORF, H. 1983. Quality and quantity of morphinan alkaloids detectable in interspecific hybrids of the genus Papaver. Planta Med. 48, 193-204.

BROCHMANN-HANSSEN, E AND WUNDERLY, S. W. 1978. Biosynthesis of morphinan alkaloids in Papaver bracteatum LindI, J. Pharm. Sci., 67, 103-106.
FAIRBAIRN, J. W. AND HELLIWELL, K. 1975. The determination of thebaine in Papaver bracteatum by gas liquid chromatography. J. Pharm. Pharmacol., 27, 217-221.

HODGES, C. C. HORN, J. S. AND RAPOPORT, H. 1977. Morphinan alkaloids in Papaver bracteatum biosynthesis and fate. Phytochemistry, 16, 1939-1942.

HORN, J. S., PAUL, A. G. AND RAPPOPORT, H. 1978. Biosynthetic conversion of thebaine to codeinone. Mechanism of ketone formation from enol ether in vivo. J. Am. Chem. Soc., 100, 1895-1898.

LALEZARI, I., NASSERI, P. AND ASGHARIAN, R. 1974. Papaver bracteatum population Arya II. J. Pharm. Sci., 63, 13311332.

LEVY, A., PALEVITCH, D. AND LAVIE, D. 1979. Thebaine yield components in selections of Arya I and Arya II populations of Papaver bracteatum. Planta Med. 36, 362-368.

MILO, J. AND LEVY, A. 1989. Effect of ploidy level on the spectrum of alkaloids in interspecific hybrids of Papaver section Oxytona. XII Eucarpia Congress 1989, Book of Poster Abstracts, 20-7.

MILO, J., LEVY, A., LADIZINSKY, G. AND PALEVITCH, D. 1988. Phylogenetic and genetic studies in Papaver section $O x y$ tona: cytogenetics, isozyme analysis and chloroplast DNA variation. Theor. Appl. Genet. 75, 795-802.

MILO, J., LEVY, A., PALEVITCH, D. AND LADIZINSKY, G. 1989. High performance liquid chromatographic analysis of the alkaloid spectrum in the roots and capsules of the species and hybrids of Papaver section Oxytona. J. Chromatogr., 452, 563-570.

NYMAN, U. AND BRUHN, J. G. 1979. Papaver bracteatum-a summary of current knowledge. Planta Med., 35, 97-117.

PHILLIPSON, J. D. 1983. Infraspecific variation and alkaloids of Papaver species. Planta Med., 48, 187-192.

SHAFIEE, A., LALEZARI, I. ASSADI, F. AND KHALAFI, F. 1977. Alkaloids of Papaver orientale L. J. Pharm. Sci., 66, 1050 1052 .

SHAFIEE, A., LALEZARI, I., NASSERI-NAURI, P. AND ASGHARIAN, R. 1975. Alkaloids of Papaver orientale and Papaver pseudo-orientale. J. Pharm. Sci., 64, 1570-1572.

STERMITZ, F. R. AND RAPOPORT, H. 1961. The biosynthesis of opium alkaloids. Alkaloids interconversions in Papaver somniferum and P. orientale. J. Am. Chem. Soc., 83, 40454050 .

WALLER, R. AND NOWACKI, E. K. 1978. Genetic control of alkaloid production. In Alkaloid Biology and Metabolism in Plants, Plenum Press, New York, pp. 49-83. 